\title{
Associations Between Pedometer-Determined Physical Activity and Adiposity in Children and Adolescents: Systematic Review
}

\author{
María L. Miguel-Berges, MSc, BsC, ${ }^{\dagger} \dagger$ John J. Reilly, MD, PhD, $\ddagger$ Luis A. Moreno Aznar, MD, PhD, ${ }^{\star} † \S \rrbracket$ and \\ David Jiménez-Pavón, $\mathrm{PhD}^{\star} \|$
}

\begin{abstract}
Objective: The present review sought to examine the evidence on the associations between pedometer-determined physical activity and adiposity. Design: Of 304 potentially eligible articles, 36 were included. A search for observational studies was carried out using Cochrane Library (CENTRAL), the OVID (MEDLINE, Embase, and PsycINFO), EBSCOhost (Sportdiscus), and PEDro database from their commenced to July 2015. Of 304 potentially eligible articles, 36 were included. Results: Most studies (30/36; $83 \%$ ) were cross sectional and all used proxies for adiposity, such as body mass index (BMI) or BMI z-score as the outcome measure. Few studies $(2 / 36 ; 6 \%)$ focused on preschool children. There was consistent evidence of negative associations between walking and adiposity; significant negative associations were observed in $72 \%(26 / 36)$ of studies overall. Conclusions: The present review supports the hypothesis that higher levels of walking are protective against child and adolescent obesity. However, prospective longitudinal studies are warranted; there is a need for more research on younger children and for more "dose-response" evidence.
\end{abstract}

Key Words: pedometers, physical activity, obesity

(Clin J Sport Med 2017;0:1-12)

\section{INTRODUCTION}

A high proportion of youth in Europe and the United States do not meet current physical activity (PA) guidelines, highlighting the importance of promoting a physically active lifestyle among youth, despite the increasing recognition of the health benefits associated with PA participation. ${ }^{1}$ Physical activity levels play a determinant role in the onset and development of obesity as well as in the maintenance of overall health in youth. ${ }^{2}$ The use of objective methods for measuring PA has been highlighted as necessary for a proper understanding of associations of PA with health-related parameters such as adiposity. ${ }^{1}$

Since pedometers were suggested for the first time in 1997 as a potential tool for monitoring daily or weekly PA in children, ${ }^{2}$ several reviews have been focused on the utility of pedometers for measuring PA. ${ }^{3-9}$ Pedometers have been used successfully in a variety of ways to promote PA among youth, ${ }^{6}$ and the validity of pedometers has been studied in depth, raising this method as appropriate. ${ }^{3,4,7-9}$ Moreover, Tudor-Locke et $\mathrm{al}^{5}$ revised the evidence on the

\footnotetext{
Submitted for publication September 30, 2016; accepted November 25, 2016.

From the *GENUD (Growth, Exercise, Nutrition and Development) Research Group, University of Zaragoza, Zaragoza, Spain; 'Instituto Agroalimentario de Aragón (IA2);

${ }^{\ddagger}$ Division of Developmental Medicine, Yorkhill Hospitals, University of Glasgow Medical Faculty, Glasgow, Scotland; §Faculty of Health Science, University of Zaragoza,

Zaragoza, Spain; "Centro de Investigación Biomédica en Red de Fisiopatología de la Obesidad y Nutrición (CIBERObn); and "GALENO Research Group, Department of Physical Education, University of Cádiz, Puerto Real (Cádiz) Spain.

The authors report no conflicts of interest.

Corresponding Author: María L. Miguel-Berges, MSc, BsC, Pedro Cerbuna, 12, 50009 Zaragoza, Spain (mlmiguel@unizar.es).

Copyright (C) 2017 Wolters Kluwer Health, Inc. All rights reserved.

http://dx.doi.org/10.1097/JSM.0000000000000419
}

number of steps per day which should be recommended and concluded that this should range from approximately 12000 to 16000 and from 10000 to 14000 steps per weekday in boys and girls, respectively (on weekend days allowing for an average decrease of 2000 steps/d). Duncan et $\mathrm{al}^{10}$ proposed a similar optimal step count cutoff point based on associations with body fat (16000 and 13000 steps/d for boys and girls, respectively).

In recent years, there has been an increased interest in objective monitoring of daily PA using simple and inexpensive methods; however, it is not clear whether pedometers could provide a suitably accurate estimate of PA to enable the detection of a significant association with adiposity or not. Jiménez-Pavón et al, ${ }^{1}$ who reviewed the literature in 2008 , found consistent evidence of negative associations between objectively measured physical activity and adiposity, although few studies used pedometers at that time. More recent reviews on associations between objectively measured PA, particularly moderate-to-vigorous PA (MVPA), and adiposity have noted a very limited evidence base. ${ }^{11}$

The wide variety of accelerometer data reduction methods in the literature also means that it is difficult to determine a dose-response association between accelerometer measured MVPA and adiposity. Walking behavior, as measured by pedometers, is a much simpler concept than MVPA, leading to simpler measurement and lending itself to simpler translation to public health messages. Therefore, because of the growing number of studies using pedometers, and the public health value of walking as a concept, and the practical utility of pedometers in population-based approaches to obesity prevention, an updated revision regarding the association of PA determined by pedometers and adiposity would be of interest. In the present review, 
the main objective was to systematically review the original studies investigating the relationship between walking and adiposity of children and adolescents.

\section{METHODS}

The protocol used for the systematic review is Preferred Reporting Items for Systematic reviews and Meta Analyses (PRISMA). ${ }^{12}$ For the assessment of the quality of the included studies where it are shown in the Table 3, was used The Evidence Analysis Manual was created by the Academy of Nutrition and Dietetics. ${ }^{13}$

\section{Search Strategy}

The search was conducted in the following databases-Cochrane Library (CENTRAL), the OVID (MEDLINE, Embase, and PsycINFO), EBSCOhost (Sportdiscus), and PEDro-from the beginning to July 2015. PubMed database was also used for double checking. The search period was chosen as pedometer usage is recent, and we wanted to include all the literature available. In addition, manual searching of reference lists were carried out and results combined in EndNote. Keywords used were "pedometer" and "pedometer and physical activity."

The searches by these terms resulted in 304 potentially eligible articles, from which duplicates, checking titles, and

\begin{tabular}{|c|c|c|c|c|c|}
\hline Study & Exposure Variable & Outcome Variable & Location/Participants & Conclusions & $\begin{array}{l}\text { Overall } \\
\text { Result }\end{array}$ \\
\hline \multirow[t]{5}{*}{14} & $\begin{array}{l}\text { Number of daily steps } 7 \text { days, waking } \\
\text { hours (pedometer Digiwalker SW-200) }\end{array}$ & Continuous variable & $\begin{array}{l}\mathrm{N}=589 \text { children ( } 310 \text { intervention, } \\
287 \text { boys) aged } 7-11 \text { years at baseline } \\
10 \text { months intervention, Northeast of } \\
\text { England }\end{array}$ & $\begin{array}{l}\text { Both control and intervention } \\
\text { participants had increased their } \\
\text { physical activity at follow-up. There } \\
\text { was no clear effect of increased PA on } \\
\text { body composition. }\end{array}$ & (NA) \\
\hline & & BMl & & & \\
\hline & & WC & & & \\
\hline & & SC and TC skinfolds & & & \\
\hline & & $\%$ body fat & & & \\
\hline \multirow[t]{2}{*}{16} & $\begin{array}{l}\text { Number of daily steps } 4 \text { consecutive } \\
\text { weekdays (Yamax pedometers } \\
\text { Digiwalker SW-200, Tokyo, Japan) }\end{array}$ & Continuous variable & $\begin{array}{l}\mathrm{N}=93 \text { children aged } 7-14 \text { years at } \\
\text { baseline } 3 \text {-year follow-up, Sweden }\end{array}$ & $\begin{array}{l}\text { Year 3: an SIG increase in BMI in boys } \\
\text { and girls, while an SIG decrease in } \\
\text { daily steps in. boys were found. }\end{array}$ & - \\
\hline & & $\mathrm{BMI}$ & & & \\
\hline \multirow[t]{4}{*}{17} & $\begin{array}{l}\text { Number of daily steps } 7 \text { consecutive } \\
\text { days ( } 5 \text { times) (Yamax Digiwalker SW- } \\
\text { 200) }\end{array}$ & Categorical variable & $\begin{array}{l}\mathrm{N}=177 \text { children (89 intervention, } 45 \\
\text { boys) aged } 6-9 \text { years at baseline } 2- \\
\text { year intervention, The Czech Republic }\end{array}$ & $\begin{array}{l}\text { Year 1: PA increase and the odds of } \\
\text { being overweight or obese in the } \\
\text { intervention children were almost } 3 \\
\text { times lower than that of control } \\
\text { children. Year 2: these odds steadily } \\
\text { decreased with the duration of the } \\
\text { intervention. }\end{array}$ & - \\
\hline & & Obesity & & & \\
\hline & & Overweight & & & \\
\hline & & Normal weight & & & \\
\hline \multirow[t]{2}{*}{19} & $\begin{array}{l}\text { Number of daily steps } 8 \text { consecutive } \\
\text { days (Yamax pedometer, Tokyo, } \\
\text { Japan, MLS-2000) }\end{array}$ & Continuous variable & $\begin{array}{l}\mathrm{N}=606 \text { ( } 315 \text { girls) aged } 9.8 \text { years at } \\
\text { baseline } 12 \text {-week intervention, } \\
\text { Arizona, United States }\end{array}$ & $\begin{array}{l}\text { Results indicated the treatment was } \\
\text { effective at increased PA level of } \\
\text { children, especially girls. NSIG } \\
\text { differences between were found for } \\
\text { BMI. }\end{array}$ & (NA) \\
\hline & & BMI & & & \\
\hline \multirow[t]{4}{*}{20} & $\begin{array}{l}\text { Number of daily steps } 4 \text { days (including } \\
\text { weekend day) (Yamax Digiwalker } \\
\text { SW700, Tokyo, Japan) }\end{array}$ & Categorical variable & $\begin{array}{l}\mathrm{N}=85 \text { girls, aged } 16 \text { year, } 12 \text {-week } \\
\text { intervention, Australia }\end{array}$ & $\begin{array}{l}\text { PA increases do not provide } \\
\text { postintervention changes in any group } \\
\text { for BMl. }\end{array}$ & (NA) \\
\hline & & Obesity & & & \\
\hline & & Normal weight & & & \\
\hline & & Underweight & & & \\
\hline \multirow[t]{2}{*}{18} & $\begin{array}{l}\text { Number of daily steps } 7 \text { days } \\
\text { (pedometer Omron HJ-720ITC; Omron } \\
\text { Healthcare, Lake Forest, Illinois) }\end{array}$ & Continuous variable & $\begin{array}{l}\mathrm{N}=285 \text { children (147 intervention } \\
\text { and } 138 \text { control) aged } 6-12 \text { years at } \\
\text { baseline } 9 \text {-month intervention, } \\
\text { Singapore }\end{array}$ & $\begin{array}{l}\text { PA increases do not provide changes in } \\
\text { BMI }\end{array}$ & (NA) \\
\hline & & BMI & & & \\
\hline
\end{tabular}


304 papers identified in the search

Using keywords: "pedometer" + "pedometer and PA" and inclusion criteria

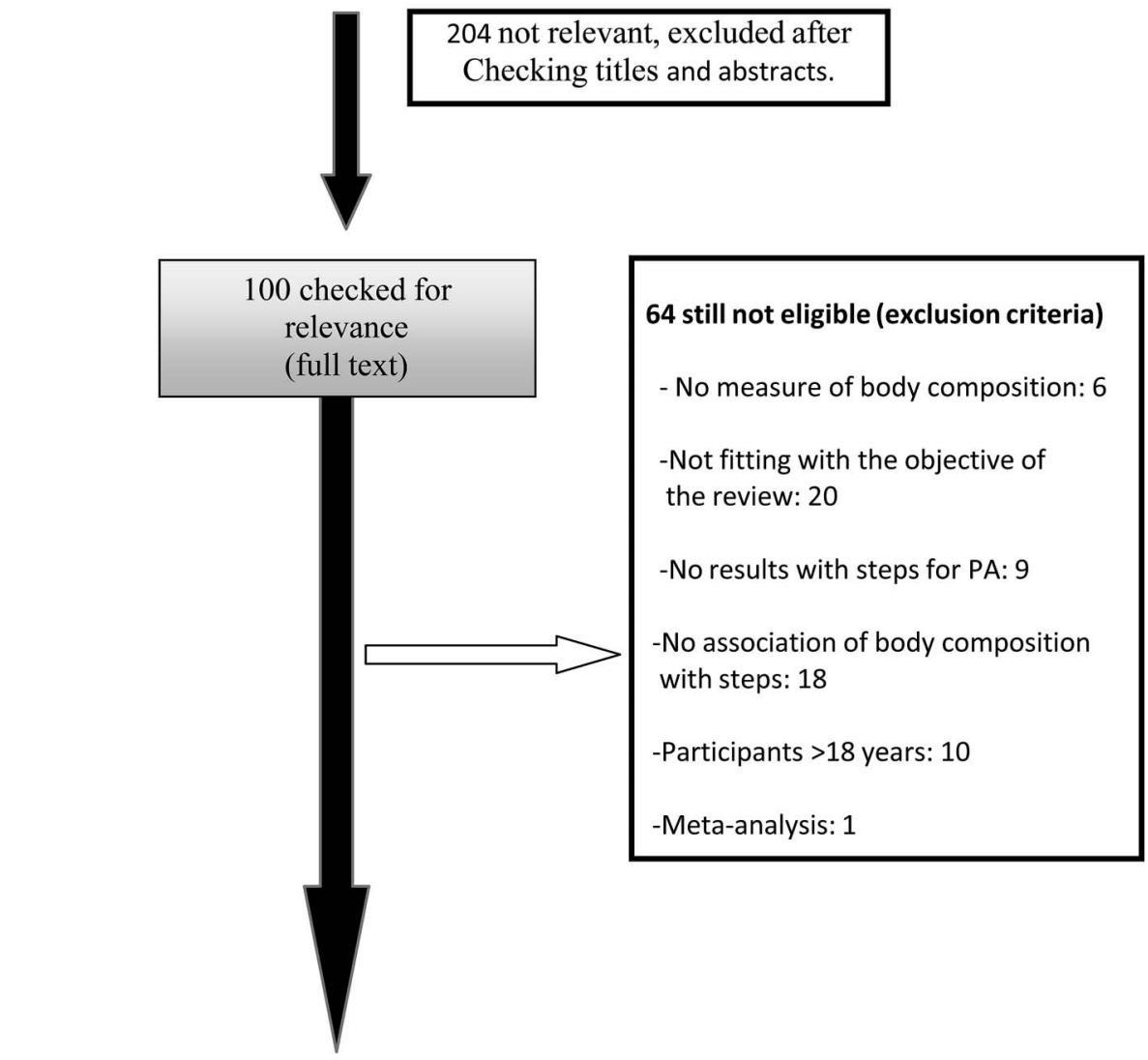

\begin{tabular}{|cc|}
\hline \multicolumn{3}{|c|}{ 36 included (elegible-inclusiom criteria) } \\
Cross-sectional & Longitudinal/Intervention \\
30 & 6 \\
\hline
\end{tabular}

Figure 1.

Flow diagram of the literature search and article selection. abstracts were eliminated by applying the inclusion and exclusion criteria derived in the final eligible articles (Figure 1).

\section{Eligibility Criteria}

Eligible studies were longitudinal and cross-sectional observational studies of healthy children and adolescents ( $0-18$ years) that tested for the existence of associations between walking using pedometers and adiposity. Studies were only included when they attempted to measure typical or "habitual" freeliving PA; studies that measured PA in confined conditions (eg, within whole-body calorimeters) were excluded. Community-based (nonclinical) studies with a measure of walking (pedometer-determined) as the exposure variable and with at least one weight-based outcome indicative of adiposity were included. Studies that used, exclusively, other objective methods for PA such as accelerometry or heart rate monitor were excluded. Studies in clinical populations, not in the English/Spanish languages, or proxy measures of habitual PA (eg, physical education time) were also excluded. In addition, duplicate publications were excluded, and in all cases of duplicates, the first publication was selected for inclusion. Doubts over eligibility of individual articles/studies were resolved by discussion and consensus between the authors. Reasons for excluding articles were noted and are available from the corresponding author on request.

\section{Data Management and Extraction}

Characteristics of each study were extracted and summarized: the exposure variable (s) used; methodology for measurement of the exposure variable; the outcome variable (s) used; methodology for measurement of the outcome variable (s) (adiposity measure, proxy, or index); sample size, location, and characteristics; and results and main conclusions relevant to the present review.

\section{Sensitivity Analyses}

\section{Age of Study Participants}

Studies were stratified by age range of study participants into preschool children (up to 5.5 years), children (5.5-10.5 


\begin{tabular}{|c|c|c|c|c|c|}
\hline Study & Exposure Variable & Outcome Variable & Location/Participants & Conclusions & $\begin{array}{l}\text { Overall } \\
\text { Result }\end{array}$ \\
\hline \multirow[t]{3}{*}{43} & \begin{tabular}{|l|} 
Number of daily steps, 4 \\
consecutive weekdays (Yamax, SW- \\
200, Digiwalker, Tokyo, Japan)
\end{tabular} & Categorical variable & $\begin{array}{l}\mathrm{N}=871 \text { children, aged } 7-9 \\
\text { years, Sweden. }\end{array}$ & $\begin{array}{l}\text { Analysis of step counts and BMls for boys } \\
\text { and girls revealed NSIG correlations in any } \\
\text { age group. }\end{array}$ & (NA) \\
\hline & & Overweight/obesity & & & \\
\hline & & Normal weight & & & \\
\hline \multirow[t]{2}{*}{45} & $\begin{array}{l}\text { Number of daily steps, } 7 \text { days } \\
\text { (Digiwalker 200SW) }\end{array}$ & Continuous variable & $\begin{array}{l}\mathrm{N}=120 \text { children, aged 9-11 } \\
\text { years, United States. }\end{array}$ & $\begin{array}{l}\text { Overweight children were more sedentary at } \\
\text { baseline than underweight and normal } \\
\text { weight children (cross-sectional data) }\end{array}$ & - \\
\hline & & BMI $\left(\mathrm{kg} / \mathrm{m}^{2}\right)$ & & & \\
\hline \multirow[t]{2}{*}{30} & $\begin{array}{l}\text { Number of daily steps, } 7 \text { days (at } \\
\text { least } 4 \text { days; } 3 \text { weekdays and } 1 \\
\text { weekend) (Yamax Digiwalker SW- } \\
\text { 200) }\end{array}$ & Continuous variable & $\begin{array}{l}\mathrm{N}=301 \text { (153 boys) aged 6-9 } \\
\text { years, Dublin. }\end{array}$ & $\begin{array}{l}\text { Significant differences were found in normal } \\
\text { and overweight, and normal and obese } \\
\text { children's step counts }\end{array}$ & 一 \\
\hline & & $\mathrm{BMI}\left(\mathrm{kg} / \mathrm{m}^{2}\right)$ & & & \\
\hline \multirow[t]{8}{*}{33} & $\begin{array}{l}\text { Number of daily steps, } 3 \text { weekdays } \\
\text { and } 2 \text { weekend days (pedometers } \\
\text { Model NL-2000, New Lifestyles) }\end{array}$ & Categorical variable & $\begin{array}{l}\mathrm{N}=1115 \text { children (536 boys) } \\
\text { aged } 5-12 \text { (8.5) years, New } \\
\text { Zealand. }\end{array}$ & Categorical variable & - \\
\hline & & Normal weight & & $\begin{array}{l}\text { SIG difference in weekend PA among the } \\
\text { weight status categories }\end{array}$ & \\
\hline & & Overweight & & & \\
\hline & & Obesity & & & \\
\hline & & Continuous variables & & Continuous variables & \\
\hline & & $\mathrm{BMI}\left(\mathrm{kg} / \mathrm{m}^{2}\right)$ & & $\begin{array}{l}\text { SIG negative associations between PA } \\
\text { and \%BF, BMl, and WC. Stronger } \\
\text { association with \%BF categories }\end{array}$ & \\
\hline & & WC & & & \\
\hline & & $\%$ BF (by BIA) & & & \\
\hline \multirow[t]{6}{*}{35} & $\begin{array}{l}\text { Step count quartiles-I: <10 000; II: } \\
10000-12 \text { 000; III: } 12 \text { 000-14 000; } \\
\text { and IV: > }>14000,7 \text { days (at least } 4 \\
\text { days; } 3 \text { weekdays and } 1 \text { weekend). } \\
\text { (Digiwalker 200SW) }\end{array}$ & Categorical variables & $\begin{array}{l}\mathrm{N}=608 \text { children, aged } 9.6 \\
\text { years, United States. }\end{array}$ & Categorical variables & 一 \\
\hline & & Overweight & & $\begin{array}{l}\text { SIG increase in odds of overweight and } \\
\text { obesity and high WC with lower count } \\
\text { quartiles }\end{array}$ & \\
\hline & & Obese & & & \\
\hline & & Continuous variables & & Continuous variables & \\
\hline & & BMl $\left(\mathrm{kg} / \mathrm{m}^{2}\right)$ & & $\begin{array}{l}\text { SIG negative associations between step } \\
\text { count, BMI, and WC }\end{array}$ & \\
\hline & & WC & & & \\
\hline \multirow[t]{7}{*}{36} & $\begin{array}{l}\text { Number of daily steps, } 3 \text { days } \\
\text { (pedometer Yamax Digiwalker SW- } \\
\text { 200) }\end{array}$ & Categorical variables & $\begin{array}{l}\mathrm{N}=315 \text { children (162 boys), } \\
\text { aged } 9-13 \text { years, London. }\end{array}$ & Categorical variables & 一 \\
\hline & & Underweight & & $\begin{array}{l}\text { Male and female obese individuals had } \\
\text { the lowest total step counts per day }\end{array}$ & \\
\hline & & Normal weight & & & \\
\hline & & Overweight & & & \\
\hline & & Obese & & & \\
\hline & & Continuous variables & & Continuous variables & \\
\hline & & BMI Z-score & & $\begin{array}{l}\text { There was a SIG negative correlation } \\
\text { between BMI z-scores and number of } \\
\text { steps per day in girls }\end{array}$ & \\
\hline 39 & $\begin{array}{l}\text { Number of daily steps, } 7 \text { days (at } \\
\text { least } 4 \text { days; } 3 \text { weekdays }\end{array}$ & Categorical variables & $\begin{array}{l}\mathrm{N}=709 \text { children, aged } 7-12 \\
\text { years, United States. }\end{array}$ & Categorical variables & 一 \\
\hline
\end{tabular}




\section{TABLE 2. Cross-Sectional Studies of Associations Between Walking Behavior by Pedometers and Adiposity in Youth (Continued)}

\begin{tabular}{|c|c|c|c|c|c|}
\hline Study & Exposure Variable & Outcome Variable & Location/Participants & Conclusions & $\begin{array}{l}\text { Overall } \\
\text { Result }\end{array}$ \\
\hline & $\begin{array}{l}\text { and } 1 \text { weekend) (pedometer } \\
\text { Digiwalker SW-200) }\end{array}$ & & & & \\
\hline & & Underweight & & $\begin{array}{l}\text { Boys and girls accumulating fewer than } \\
13000 \text { and } 11000 \text { steps per day, } \\
\text { respectively, were } 2.74 \text { and } 2.37 \text { times } \\
\text { more likely to be overweight than those } \\
\text { that met the recommendations }\end{array}$ & \\
\hline & & Normal weight & & & \\
\hline & & Overweight & & & \\
\hline & & Obese & & & \\
\hline & & Continuous variables & & Continuous variables & \\
\hline & & $\mathrm{BMI}$ & & $\begin{array}{l}\text { There was a SIG negative correlation } \\
\text { between BMI and number of steps per } \\
\text { day in boys and girls }\end{array}$ & \\
\hline \multirow[t]{3}{*}{32} & $\begin{array}{l}\text { Number of daily steps, } 3 \text { weekdays } \\
\text { (pedometer Yamax SW-200 } \\
\text { Digiwalker, Yamasa Corp., Tokyo, } \\
\text { Japan) }\end{array}$ & Continuous variables & $\begin{array}{l}\mathrm{N}=178 \text { children, aged } 9-12 \\
\text { years, Canada. }\end{array}$ & $\begin{array}{l}\text { BMI z-Score and WC were negatively } \\
\text { correlated with pedometer step counts }\end{array}$ & - \\
\hline & & BMl z-score & & & \\
\hline & & WC z-score & & & \\
\hline \multirow[t]{7}{*}{34} & $\begin{array}{l}\text { Number of daily steps, } 4 \\
\text { consecutive days ( } 2 \text { weekdays, } 2 \\
\text { weekend days) (pedometer New } \\
\text { Lifestyles, NL-2000, Montana, USA) }\end{array}$ & Categorical variables & $\begin{array}{l}\mathrm{N}=496 \text { children ( } 224 \text { boys) } \\
\text { aged 8-14 years, England. }\end{array}$ & Categorical variables & - \\
\hline & & Normal weight & & $\begin{array}{l}\text { PA in the weekdays SIG decreases across } \\
\text { weight status categories in children }\end{array}$ & \\
\hline & & Overweight & & & \\
\hline & & Obese & & & \\
\hline & & Continuous variables & & Continuous variables & \\
\hline & & $\mathrm{BMl}$ & & $\begin{array}{l}\text { Mean steps taken during weekend days } \\
\text { are SIG associated with reduced BMI } \\
\text { and LBMI in children }\end{array}$ & \\
\hline & & LBMI & & & \\
\hline \multirow[t]{10}{*}{28} & $\begin{array}{l}\text { Number of daily steps, } 3 \\
\text { consecutive weekdays (pedometer } \\
\text { Digiwalker) }\end{array}$ & Categorical variables & $\begin{array}{l}N=224 \text { (109 boys) aged 3, 4- } \\
6 \text {, and } 4 \text { years, Arabia Saudi. }\end{array}$ & Categorical variables & (NA) \\
\hline & & Nonobese & & $\begin{array}{l}\text { Nonobese children had higher steps } \\
\text { count per day than obese peers } \\
\text { (7064.5 versus } 5374.6) \text {, but the } \\
\text { difference was NSIG. }\end{array}$ & \\
\hline & & Obese & & & \\
\hline & & Continuous variables & & Continuous variables & \\
\hline & & Sum of $2 \mathrm{SC}$ and TC & & $\begin{array}{l}\text { No differences were found between } \\
\text { active }(\geq 10000) \text { and inactive children } \\
\text { for any of the adiposity indexes } \\
\text { calculated }\end{array}$ & \\
\hline & & FMI & & & \\
\hline & & $\% F M$ & & & \\
\hline & & $\mathrm{FM}$ & & & \\
\hline & & FFM & & & \\
\hline & & FFMI & & & \\
\hline 38 & $\begin{array}{l}\text { Number of daily steps, } 8 \text { days (at } \\
\text { least } 4 \text { days) (pedometer Yamax } \\
\text { Digiwalker SW-700) }\end{array}$ & Categorical variables & $\begin{array}{l}\mathrm{N}=1539 \text { adolescents }(787 \\
\text { boys) aged } 9-16 \text { years, } \\
\text { Australia. }\end{array}$ & Categorical variables & - \\
\hline
\end{tabular}




\section{TABLE 2. Cross-Sectional Studies of Associations Between Walking Behavior by Pedometers and Adiposity in Youth (Continued)}

\begin{tabular}{|c|c|c|c|c|c|}
\hline Study & Exposure Variable & Outcome Variable & Location/Participants & Conclusions & $\begin{array}{l}\text { Overall } \\
\text { Result }\end{array}$ \\
\hline & & $\begin{array}{l}\text { Normal vs high trunk fat } \\
\text { (WC) }\end{array}$ & & $\begin{array}{l}\text { There were a trend to higher levels of PA } \\
\text { in normal weight group compared with } \\
\text { the ow/ob group, but only SIG in the } \\
\text { age groups } 9-10 \text { and } 9-11 \text { years in } \\
\text { boys and girls, respectively. Similarly, } \\
\text { those with normal trunk fat had higher } \\
\text { PA levels compared with those with } \\
\text { high trunk fat in age groups } 15-16 \text { and } \\
7-12 \text { years in boys and girls, } \\
\text { respectively }\end{array}$ & \\
\hline & & $\begin{array}{l}\text { obese versus normal } \\
\text { weight }\end{array}$ & & & \\
\hline & & Continuous variables & & Continuous variables & $\begin{array}{l}M(-), F \\
(N A)\end{array}$ \\
\hline & & $\mathrm{BMl}$ & & $\begin{array}{l}\text { There was no relationship between BMl } \\
\text { and mean daily steps count for either } \\
\text { male or females and only a small but } \\
\text { significant relationship between WC } \\
\text { and PA for males }\end{array}$ & \\
\hline & & WC & & & \\
\hline \multirow[t]{7}{*}{27} & $\begin{array}{l}\text { Number of daily steps, } 3 \text { continuous } \\
\text { weekdays (pedometer Yamax } \\
\text { Digiwalker SW-701) }\end{array}$ & Categorical variables & $\begin{array}{l}N=296 \text { children aged 8-12 } \\
\text { years, Arabia Saudi. }\end{array}$ & Categorical variables & 一 \\
\hline & & $\begin{array}{l}\text { Obese versus normal } \\
\text { weight }\end{array}$ & & $\begin{array}{l}\text { Mean step counts for the obese group } \\
\text { were significantly lower than in the } \\
\text { normal group }\end{array}$ & \\
\hline & & $\begin{array}{l}\text { Obesity ( }>25 \% \mathrm{FM}) \text { versus } \\
\text { normal weight }\end{array}$ & & Continuous variables & \\
\hline & & Continuous variables & & & \\
\hline & & TC and SC skinfolds & & $\begin{array}{l}\text { There were SIG differences between } \\
\text { active (>13000 steps/day) and } \\
\text { inactive boys in body weight, BMI, } \\
\text { triceps and subscapular skinfolds, \% } \\
\text { FM, and FMl }\end{array}$ & \\
\hline & & FM & & & \\
\hline & & FMl & & & \\
\hline \multirow[t]{3}{*}{29} & $\begin{array}{l}\text { Number of daily steps, } 4 \\
\text { consecutive weekdays (pedometer } \\
\text { Walk4Life MLS 2525, Plainfield, IL, } \\
\text { and YAMAX SW-200, Tokyo, Japan } \\
\text { for the } 60 \% \text { and } 40 \% \text { of the sample, } \\
\text { respectively) }\end{array}$ & Categorical variables & $\begin{array}{l}\mathrm{N}=1067 \text { children (434 boys) } \\
\text { aged } 6-12 \text { years, United States. }\end{array}$ & $\begin{array}{l}\text { Descriptive information shows a tendency to } \\
\text { lower levels of PA in those at risk of overview } \\
\text { compared with normal weight, but no } \\
\text { statistical analyses were performed. Further } \\
\text { analyses showed that steps counts were } \\
\text { unable to distinguish between youth in } \\
\text { a healthy or unhealthy weight. }\end{array}$ & (NA) \\
\hline & & Normal weight & & & \\
\hline & & At risk of an overweight & & & \\
\hline \multirow[t]{3}{*}{41} & $\begin{array}{l}\text { Number of daily steps, } 7 \text { days } \\
\text { (pedometer Lifecorder EX, Suzuken } \\
\text { Co., Nagoya, Japan) }\end{array}$ & Continuous variables & $\begin{array}{l}\mathrm{N}=216 \text { (105 boys) aged } 9-10 \\
\text { years, Japan. }\end{array}$ & $\begin{array}{l}\text { The steps counts were negatively correlated } \\
\text { with obesity indices in both sexes (stronger } \\
\text { in girls) }\end{array}$ & - \\
\hline & & $\mathrm{BMI}$ & & & \\
\hline & & $\% B F$ by BIA & & & \\
\hline \multirow[t]{4}{*}{42} & $\begin{array}{l}\text { Number of daily steps, } 2 \text { weekdays } \\
\text { (pedometer Yamax SW-200 } \\
\text { Digiwalker, Yamasa Corp., Tokyo, } \\
\text { Japan) }\end{array}$ & Categorical variables & $\begin{array}{l}\mathrm{N}=82 \text { adolescents (34 males) } \\
\text { aged } 9-12 \text { years, } \mathrm{E} \text { Canada. }\end{array}$ & $\begin{array}{l}\text { The pedometer step counts did not differ } \\
\text { among body weight categories }\end{array}$ & (NA) \\
\hline & & Normal weight & & & \\
\hline & & Overweight & & & \\
\hline & & Obese & & & \\
\hline
\end{tabular}




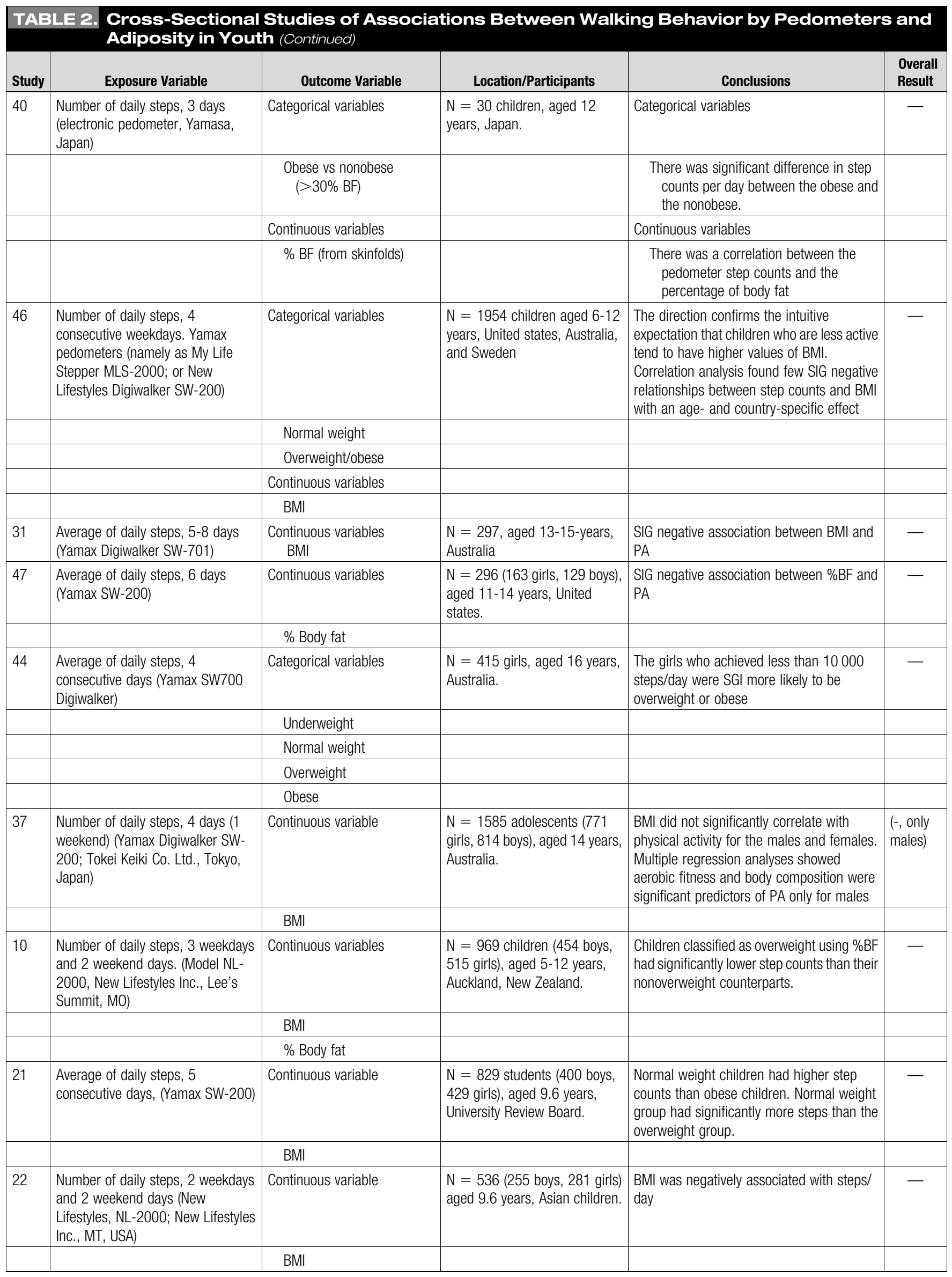




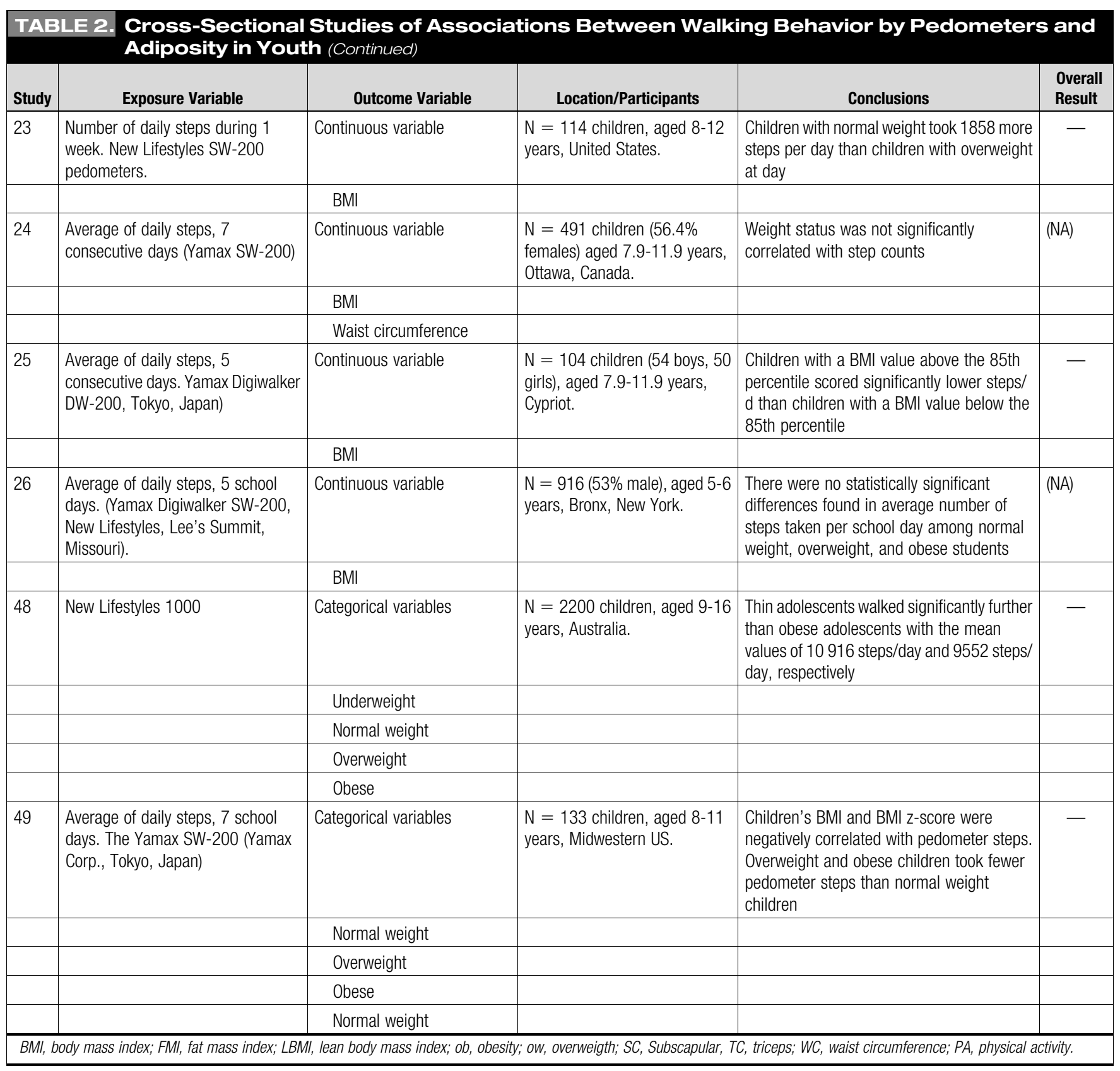

years), and adolescents (10.5-18 years) to examine possible age-dependence of relationships between walking and adiposity. ${ }^{14}$ The precise age categories chosen made little difference to the conclusions of the present review.

\section{Outcome Measure(s)}

A variety of different measures of adiposity or indices of adiposity were used in the studies reviewed, falling into 2 categories: proxies for adiposity [body mass index (BMI) and waist circumference] and more precise measures of adiposity such as skinfolds thickness or bioelectrical impedance analysis (BIA).

\section{Exposure Measure}

The method used to measure PA was only pedometry. This has become a popular PA assessment tool, ${ }^{10}$ capturing objective PA data, ${ }^{8}$ specifically walking behavior.

\subsection{Sample Size}

The studies reviewed were characterized by a very wide range of sample sizes. Sample size is likely to determine the ability to detect associations between walking behavior and adiposity. Publication bias is also possible, and small studies that find no association between walking and adiposity are less likely to be published than small studies that find significant associations. In an attempt to address the influence of sample size on the confidence in any conclusions reached, studies were categorized by sample size in the present review as "large studies" $\mathrm{n}>1000$ participants; "medium sized studies," $\mathrm{n} \geq 100$ to 1000 participants; and "small studies," $\mathrm{n}<100$ participants.

\section{Consistency of Evidence}

The scheme proposed by Sallis et $\mathrm{al}^{15}$ was used to summarize the consistency of the body of evidence as 
previously used to infer the degree of confidence in the conclusions. "Strong evidence" of an association exists when $60 \%-100 \%$ of studies find significant associations in the same direction.

\section{RESULTS}

\section{Overall Results}

Of the 304 potentially eligible articles, 36 were eligible and included and are summarized in the present review (Figure 1 is a flow diagram describing the search and selection process).

Only $17 \%(6 / 36)$ of eligible studies were longitudinal ${ }^{14,16-20}$ (Table 1), from which $83 \%$ (5/6) were intervention studies. Most studies [83\% (30/36)] were cross sectional ${ }^{10,21-49}$ (Table 2). Only 6\% (2/36) of studies focused on children younger than 5.5 years old. Most studies [80\% (29/36)] included children and adolescents aged 5.5 to 10.5 years, whereas $5 / 36(14 \%)$ studies included adolescents aged $>10.5$ to 18 years. However, all the studies included BMI as a proxy for adiposity, and $19 \%$ of studies (7/36) also measured waist circumference. However, only $25 \%$ (9/36) of studies used more precise measures of body composition such as skinfolds and/or BIA. The studies reviewed here consistently reported significant and negative associations between walking and adiposity (25/ $35 ; 71 \%)$, indicating "strong evidence" that such an association exists with higher levels of walking being associated with lower measures or indices of adiposity. In the cross-sectional studies, $24 / 30(80 \%)$ of them found significant negative associations, and in the longitudinal studies, $2 / 6(33 \%)$ of studies found significant negative associations while the other studies found a nonsignificant trend in the "expected" direction.

\section{Results by Outcome Measure}

Significant negative associations between pedometerdetermined physical activity and adiposity were found in 16/ $23(70 \%)$ of studies that used simple proxies for adiposity as the outcome measure and 10/13 (77\%) of studies that used more precise body composition variables such as skinfolds and waist circumference as the outcome measure.

\section{Results by Sample Size}

$7 / 36(19 \%)$ of studies were "large" (n > 1000 participants), $25 / 36(69 \%)$ "medium size" ( $n=100-1000$ participants), and $4 / 36(11 \%)$ "small size" ( $<100$ participants). 86\% (6/7) of the large studies found significant negative associations, whereas the corresponding percentage was $72 \%(18 / 25)$ in the medium sized studies and 50\% (2/4) in the small studies.

\section{Results by Pedometers Model}

Twenty of $36(56 \%)$ of studies used the same pedometer model, the Yamax Digiwalker SW-200 series which has consistently been found among the most accurate of the pedometers. The Yamax SW-200 is recommended as a reliable monitor for use in children ${ }^{2}$ and is the most commonly used pedometer to assess PA and walking among children. ${ }^{49}$
Only one meta-analysis was found, and the results support the fact that the use of pedometers has a moderate and positive effect on the increase of PA in intervention studies.

\section{DISCUSSION}

The studies summarized in the present review represent a large body of evidence that reported significant and negative associations between pedometer-determined physical activity and adiposity with a high degree of consistency, probably indicating "strong evidence" that such an association exists. ${ }^{15}$ The present review therefore supports the view that variation in the level of walking in youth is a contributor to variation in weight status. This study supports the hypothesis that higher levels of walking are protective against increased adiposity in youth and so supports the use of walking as a promotion as a strategy for obesity prevention.

This study found a number of evidence gaps and weaknesses which future research could address. Relatively few studies tested for associations between pedometerdetermined physical activity and adiposity in the preschool population, and among the studies on school-age children and adolescents, there were far fewer studies of adolescents than children. Many studies did not consider differences in associations between pedometer-determined physical activity and adiposity between the sexes, but it may be noteworthy that the evidence summarized here contained a suggestion that significant negative associations may be found more commonly among boys than girls and that associations may be stronger in boys than girls. Future research would be required to address the issue of sex differences more conclusively, but boys are usually more physically active than girls, as suggested by many reviews, $1,2,6,8,9,14,29,35,36,41,43$ and in a previous systematic review of associations between accelerometer measured physical activity (not specifically walking) and adiposity in youth, there was a suggestion of consistently stronger associations in boys than girls. ${ }^{1}$

Numerous descriptive studies have implemented pedometers to assess weekday walking in children and adolescents, yet comparatively few have obtained separate data representing weekend days. The number of steps taken by children on the weekends is of particular interest, given the current evidence that young people are less active when outside the school environment. ${ }^{3}$ The strong associations highlighted in this review provide support to the use of pedometers in studies of the etiology of obesity in youth, although the limitations of measuring only the numbers of steps should always be considered, and where resources permit alternative methods of measuring physical activity (eg accelerometry) should also be considered. Only one meta-analysis was found, and the results support the fact that the use of pedometers has a moderate and positive effect on the increase of PA in intervention studies. ${ }^{50}$

Publication bias may well have influenced the literature on associations between pedometer-determined physical activity and adiposity in youth. No formal test for publication bias was performed in this study, but the conclusions of larger studies $(n>1000)$ reviewed were actually more supportive ( $86 \%$ of studies found significant negative associations) of the hypothesis that higher levels of walking protects against high adiposity than the conclusions of smaller studies $(n<100$; $50 \%$ of studies found significant negative associations), and this conclusion was independent of the method used to 


\begin{tabular}{|c|c|c|c|c|c|c|c|c|c|c|c|}
\hline Author & Overall & $\begin{array}{c}\text { Was the } \\
\text { Research } \\
\text { Question } \\
\text { Clearly } \\
\text { Stated? }\end{array}$ & $\begin{array}{c}\text { Was the } \\
\text { Selection } \\
\text { of Study } \\
\text { Subjects/ } \\
\text { Patients } \\
\text { Free From } \\
\text { Bias? }\end{array}$ & $\begin{array}{c}\text { Were Study } \\
\text { Groups } \\
\text { Comparable? }\end{array}$ & $\begin{array}{l}\text { Was the } \\
\text { Method of } \\
\text { Handling } \\
\text { Withdrawals } \\
\text { Described? }\end{array}$ & $\begin{array}{l}\text { Was } \\
\text { Blinding } \\
\text { Used to } \\
\text { Prevent } \\
\text { Introduction } \\
\text { of Bias? }\end{array}$ & $\begin{array}{c}\text { Were } \\
\text { Intervention/ } \\
\text { Therapeutic } \\
\text { Regimens/ } \\
\text { Exposure } \\
\text { Factor or } \\
\text { Procedure } \\
\text { and Any } \\
\text { Comparison } \\
\text { Described in } \\
\text { Detail? Were } \\
\text { Intervening } \\
\text { Factors } \\
\text { Described? }\end{array}$ & $\begin{array}{l}\text { Were Outcomes } \\
\text { Clearly Defined } \\
\text { and the } \\
\text { Measurements } \\
\text { Valid and } \\
\text { Reliable? }\end{array}$ & $\begin{array}{l}\text { Was the } \\
\text { Statistical } \\
\text { Analysis } \\
\text { Appropriate } \\
\text { for the } \\
\text { Study } \\
\text { Design and } \\
\text { Type of } \\
\text { Outcome } \\
\text { Indicators? }\end{array}$ & $\begin{array}{c}\text { Are } \\
\text { Conclusions } \\
\text { Supported by } \\
\text { Results With } \\
\text { Biases and } \\
\text { Limitations } \\
\text { Taken Into } \\
\text { Consideration? }\end{array}$ & $\begin{array}{c}\text { Is a Bias Due } \\
\text { to Study's } \\
\text { Funding or } \\
\text { Sponsorship } \\
\text { Unlikely? }\end{array}$ \\
\hline 14 & + & Yes & Yes & Yes & Yes & No & Yes & Yes & Yes & Yes & No \\
\hline 16 & + & Yes & Yes & Yes & Yes & No & Yes & Yes & Yes & Yes & Yes \\
\hline 17 & + & Yes & Yes & Yes & No & No & Yes & Yes & Yes & Yes & Yes \\
\hline 19 & - & Yes & No & No & No & No & Yes & No & No & Yes & No \\
\hline 20 & + & Yes & Yes & Yes & Yes & No & Yes & Yes & Yes & Yes & Yes \\
\hline 18 & $\emptyset$ & Yes & Yes & $\mathrm{N} / \mathrm{A}$ & No & No & N/A & No & N/A & Yes & No \\
\hline 43 & $\emptyset$ & Yes & Yes & N/A & Yes & No & Yes & Yes & Yes & Yes & Yes \\
\hline 45 & + & No & Yes & Yes & No & No & Yes & Yes & Yes & Yes & Yes \\
\hline 30 & + & Yes & Yes & Yes & No & No & Yes & Yes & Yes & Yes & Yes \\
\hline 33 & + & Yes & Yes & Yes & No & No & Yes & Yes & Yes & Yes & N/A \\
\hline 35 & - & Yes & Yes & No & No & No & No & $\mathrm{N} / \mathrm{A}$ & Yes & Yes & Yes \\
\hline 36 & $\emptyset$ & Yes & Yes & N/A & Yes & No & Yes & Yes & Yes & Yes & N/A \\
\hline 39 & $\emptyset$ & Yes & Yes & $\mathrm{N} / \mathrm{A}$ & No & No & Yes & Yes & Yes & Yes & Yes \\
\hline 32 & + & Yes & Yes & Yes & No & No & Yes & Yes & Yes & Yes & Yes \\
\hline 34 & + & Yes & Yes & Yes & Yes & No & Yes & Yes & Yes & Yes & Yes \\
\hline 28 & $\emptyset$ & Yes & Yes & N/A & No & No & Yes & Yes & Yes & Yes & Yes \\
\hline 38 & $\emptyset$ & Yes & Yes & N/A & No & No & Yes & Yes & Yes & Yes & $\mathrm{N} / \mathrm{A}$ \\
\hline 27 & + & Yes & Yes & Yes & No & No & Yes & Yes & Yes & Yes & Yes \\
\hline 29 & $\emptyset$ & Yes & Yes & $\mathrm{N} / \mathrm{A}$ & No & No & Yes & Yes & Yes & Yes & $\mathrm{N} / \mathrm{A}$ \\
\hline 41 & - & N/A & Yes & No & No & No & No & N/A & Yes & Yes & N/A \\
\hline 42 & + & Yes & Yes & Yes & No & No & Yes & Yes & Yes & Yes & $\mathrm{N} / \mathrm{A}$ \\
\hline 40 & + & Yes & Yes & Yes & No & No & Yes & Yes & Yes & No & $\mathrm{N} / \mathrm{A}$ \\
\hline 46 & + & Yes & Yes & Yes & No & No & Yes & Yes & Yes & Yes & Yes \\
\hline 31 & $\emptyset$ & Yes & Yes & No & No & No & N/A & Yes & Yes & Yes & Yes \\
\hline 47 & - & Yes & Yes & No & No & No & Yes & No & No & No & Yes \\
\hline 44 & $\emptyset$ & Yes & Yes & No & No & No & Yes & Yes & Yes & Yes & No \\
\hline 37 & - & Yes & No & No & No & No & Yes & N/A & Yes & Yes & No \\
\hline 10 & + & Yes & Yes & Yes & No & No & Yes & Yes & Yes & Yes & $\mathrm{N} / \mathrm{A}$ \\
\hline 21 & - & Yes & No & No & No & No & Yes & N/A & Yes & Yes & No \\
\hline 22 & + & Yes & Yes & Yes & No & No & Yes & Yes & Yes & Yes & N/A \\
\hline 23 & - & Yes & No & No & No & No & Yes & N/A & Yes & Yes & No \\
\hline 24 & $\emptyset$ & Yes & Yes & No & No & No & Yes & Yes & Yes & Yes & No \\
\hline 25 & $\emptyset$ & Yes & Yes & No & No & No & Yes & Yes & Yes & Yes & No \\
\hline 26 & $\emptyset$ & Yes & Yes & No & No & No & Yes & Yes & Yes & Yes & No \\
\hline 48 & + & Yes & Yes & Yes & No & No & Yes & Yes & Yes & Yes & N/A \\
\hline 49 & - & Yes & No & No & No & No & Yes & N/A & Yes & Yes & No \\
\hline
\end{tabular}

categorize sample size. An additional limitation of the literature was that because of the predominance of crosssectional studies, it is difficult to rule out bidirectionality-the possibility that higher adiposity might reduce walking.
Greater confidence about causal relationships between pedometer-determined physical activity and adiposity would also require a greater body of evidence from longitudinal and intervention studies-the present review suggests that there is 
a distinct lack of evidence from these study designs. Finally, the body of evidence identified from this study was too limited and too heterogeneous to attempt to assess "dose-response" relationships between physical activity and adiposity-future research should attempt to identify the "dose-response."

\section{CONCLUSION}

The present review supports the hypothesis that higher levels of walking behavior are against higher levels of child and adolescent adiposity. However, prospective longitudinal studies using more precise methods of body composition are warranted; there is a need for more research on younger children, in a wider variety of settings and populations, and for more "dose-response" evidence.

Detecting strong evidence of this association using pedometers not only implies its utility in monitoring walking levels but also could help us as a tool in promoting physical activity patterns by means of motivational aspects.

\section{ACKNOWLEDGMENTS}

The authors thank the researchers for contributing to research and the coauthors for their help in the search, drafting, and review the article.

\section{References}

1. Jimenez-Pavon D, Kelly J, Reilly JJ. Associations between objectively measured habitual physical activity and adiposity in children and adolescents: systematic review. Int J Pediatr Obes. 2010;5:3-18.

2. Rowlands AV, Eston RG, Ingledew DK. Measurement of physical activity in children with particular reference to the use of heart rate and pedometry. Sports Med. 1997;24:258-272.

3. Clemes SA, Biddle SJ. The use of pedometers for monitoring physical activity in children and adolescents: measurement considerations. J Phys Act Health. 2013;10:249-262.

4. McNamara E, Hudson Z, Taylor SJ. Measuring activity levels of young people: the validity of pedometers. Br Med Bull. 2010;95:121-137.

5. Tudor-Locke C, McClain JJ, Hart TL, et al. Expected values for pedometer-determined physical activity in youth. Res Q Exerc Sport. 2009;80:164-174.

6. Lubans DR, Morgan PJ, Tudor-Locke C. A systematic review of studies using pedometers to promote physical activity among youth. Prev Med. 2009;48:307-315.

7. Tudor-Locke C, Williams JE, Reis JP, et al. Utility of pedometers for assessing physical activity: construct validity. Sports Med. 2004;34: 281-291.

8. Tudor-Locke C, Williams JE, Reis JP, et al. Utility of pedometers for assessing physical activity: convergent validity. Sports Med. 2002;32: 795-808.

9. Oliver M, Schofield GM, Kolt GS. Physical activity in preschoolers: understanding prevalence and measurement issues. Sports Med. 2007;37: 1045-1070.

10. Duncan JS, Schofield G, Duncan EK. Step count recommendations for children based on body fat. Prev Med. 2007;44:42-44.

11. Ekelund U, Hildebrand M, Collings PJ. Physical activity, sedentary time and adiposity during the first two decades of life. Proc Nutr Soc. 2014;73: 319-329.

12. Liberati A, Altman DG, Tetzlaff J, et al. The PRISMA statement for reporting systematic reviews and meta-analyses of studies that evaluate health care interventions: explanation and elaboration. J Clin Epidemiol. 2009;62:e1-e34.

13. Evidence analysis manual: Steps in the academy evidence analysis process. American Dietetic Association; 2012.

14. Gorely T, Morris JG, Musson H, et al. Physical activity and body composition outcomes of the GreatFun2Run intervention at 20 month follow-up. Int J Behav Nutr Phys Act. 2011;8:74.

15. Sallis JF, Prochaska JJ, Taylor WC. A review of correlates of physical activity of children and adolescents. Med Sci Sports Exerc. 2000;32:963-975.
16. Raustorp A, Mattsson E, Svensson K, et al. Physical activity, body composition and physical self-esteem: a 3-year follow-up study among adolescents in Sweden. Scand J Med Sci Sports 2006;16:258-266.

17. Sigmund E, El Ansari W, Sigmundova D. Does school-based physical activity decrease overweight and obesity in children aged 6-9 years? A two-year non-randomized longitudinal intervention study in the Czech Republic. BMC Public Health. 2012;12:570.

18. Finkelstein EA, Tan YT, Malhotra R, et al. A cluster randomized controlled trial of an incentive-based outdoor physical activity program. J Pediatr. 2013;163:167-172.e1.

19. Pangrazi RP, Beighle A, Vehige T, et al. Impact of promoting lifestyle activity for youth (play) on children's physical activity.J Sch Health. 2003; 73:317-321.

20. Schofield L, Mummery WK, Schofield G. Effects of a controlled pedometer-intervention trial for low-active adolescent girls. Med Sci Sports Exerc. 2005;37:1414-1420.

21. Brusseau TA, Kulinna PH, Tudor-Locke C, et al. Pedometer-determined segmented physical activity patterns of fourth- and fifth-grade children. J Phys Act Health. 2011;8:279-286.

22. Duncan MJ, Birch S, Al-Nakeeb Y, et al. Ambulatory physical activity levels of white and South Asian children in Central England. Acta Paediatr. 2012;101:e156-e162.

23. Hickerson BD, Henderson KA. Opportunities for promoting youth physical activity: an examination of youth summer camps. J Phys Act Health. 2014;11:199-205.

24. Larouche R, Boyer C, Tremblay MS, et al. Physical fitness, motor skill, and physical activity relationships in grade 4 to 6 children. Appl Physiol Nutr Metab. 2014;39:553-559.

25. Loucaides CA, Jago R. Correlates of pedometer-assessed physical activity in Cypriot elementary school children. J Phys Act Health. 2006;3:267.

26. Reznik M, Wylie-Rosett J, Kim M, et al. Physical activity during school in urban minority kindergarten and first-grade students. Pediatrics. 2013; 131:e81-e87.

27. Al-Hazzaa HM. Pedometer-determined physical activity among obese and non-obese 8- to 12-year-old Saudi schoolboys. J Physiol Anthropol. 2007;26:459-465.

28. Al-Hazzaa HM, Al-Rasheedi AA. Adiposity and physical activity levels among preschool children in Jeddah, Saudi Arabia. Saudi Med J. 2007;28: 766-773.

29. Beets MW, Le Masurier GC, Beighle A, et al. Are current body mass index referenced pedometer step-count recommendations applicable to US youth? J Phys Act Health. 2008;5:665-674.

30. Belton S, Brady P, Meegan S, et al. Pedometer step count and BMI of Irish primary school children aged 6-9 years. Prev Med. 2010;50:189-192.

31. Cuddihy T, Michaud-Tomson L, Jones EK, et al. Exploring the relationship between daily steps, body mass index and physical selfesteem in female Australian adolescents. J Exerc Sci Fitness. 2006;4: $25-35$.

32. Downs SM, Marshall D, Ng C, et al. Central adiposity and associated lifestyle factors in Cree children. Appl Physiol Nutr Metab. 2008;33: 476-482.

33. Duncan JS, Schofield G, Duncan EK. Pedometer-determined physical activity and body composition in New Zealand children. Med Sci Sports Exerc. 2006;38:1402-1409.

34. Duncan MJ, Nevill A, Woodfield L, et al. The relationship between pedometer-determined physical activity, body mass index and lean body mass index in children. Int J Pediatr Obes. 2010;5:445-450.

35. Eisenmann JC, Laurson KR, Wickel EE, et al. Utility of pedometer step recommendations for predicting overweight in children. Int J Obes (Lond). 2007;31:1179-1182.

36. Finnerty T, Reeves S, Dabinett J, et al. Effects of peer influence on dietary intake and physical activity in schoolchildren. Public Health Nutr. 2010; 13:376-383.

37. Hands B, Larkin D, Parker H, et al. The relationship among physical activity, motor competence and health-related fitness in 14-year-old adolescents. Scand J Med Sci Sports. 2009;19:655-663.

38. Hands B, Parker H. Pedometer-determined physical activity, BMI, and waist girth in 7- to 16-year-old children and adolescents. J Phys Act Health. 2008;5(suppl 1):S153-S165.

39. Laurson KR, Eisenmann JC, Welk GJ, et al. Combined influence of physical activity and screen time recommendations on childhood overweight. J Pediatr. 2008;153:209-214.

40. Mikami S, Mimura K, Fujimoto S, et al. Physical activity, energy expenditure and intake in 11 to 12 years old Japanese prepubertal obese boys. J Physiol Anthropol Appl Hum Sci. 2003;22:53-60. 
41. Munakata H, Sei M, Ewis AA, et al. Prediction of Japanese children at risk for complications of childhood obesity: gender differences for intervention approaches. J Med Invest. 2010;57:62-68.

42. Ng C, Marshall D, Willows ND. Obesity, adiposity, physical fitness and activity levels in Cree children. Int J Circumpolar Health. 2006;65: 322-330.

43. Raustorp A, Pangrazi RP, Stahle A. Physical activity level and body mass index among schoolchildren in south-eastern Sweden. Acta Paediatr. 2004;93:400-404.

44. Schofield G, Schofield L, Hinckson EA, et al. Daily step counts and selected coronary heart disease risk factors in adolescent girls. J Sci Med Sport. 2009;12:148-155.

45. Southard DR, Southard BH. Promoting physical activity in children with MetaKenkoh. Clin Invest Med. 2006;29:293-297.
46. Vincent SD, Pangrazi RP, Raustorp A, et al. Activity levels and body mass index of children in the United States, Sweden, and Australia. Med Sci Sports Exerc. 2003;35:1367-1373.

47. Rowe DA, Raedeke TD, Wiersma LD, et al. Investigating the youth physical activity promotion model: internal structure and external validity evidence for a potential measurement model. Pediatr Exerc Sci. 2007;19:420-435.

48. Ferrar K, Olds T. Thin adolescents: who are they? What do they do? Sociodemographic and use-of-time characteristics. Prev Med. 2010;51:253-258.

49. Ling J, Robbins LB, McCarthy VL, et al. Psychosocial determinants of physical activity in children attending afterschool programs: a path analysis. Nurs Res. 2015;64:190-199.

50. Kang M, Marshall SJ, Barreira TV, et al. Effect of pedometer-based physical activity interventions: a meta-analysis. Res Q Exerc Sport. 2009; 80:648-655. 